Article

\title{
Lead-Antimony Sulfosalts from Tuscany (Italy). XX. Members of the Jordanite-Geocronite Series from the Pollone Mine, Valdicastello Carducci: Occurrence and Crystal Structures
}

\author{
Cristian Biagioni ${ }^{1, *}$, Andrea Dini ${ }^{2}$, Paolo Orlandi ${ }^{1,2}$, Yves Moëlo ${ }^{3}$, Marco Pasero ${ }^{1}$ and \\ Federica Zaccarini ${ }^{4}$ \\ 1 Dipartimento di Scienze della Terra, Università di Pisa, Via Santa Maria 53, I-56126 Pisa, Italy; \\ paoloorlandi.pisa@gmail.com (P.O.); marco.pasero@unipi.it (M.P.) \\ 2 Istituto di Geoscienze e Georisorse, CNR, Via Moruzzi 1, I-56124 Pisa, Italy; a.dini@igg.cnr.it \\ 3 Institut des Matériaux Jean Rouxel, UMR 6502, CNRS, Université de Nantes, 2 rue de la Houssinière, \\ F-44322 Nantes Cedex 3, France; Yves.Moelo@cnrs-imn.fr \\ 4 Resource Mineralogy, University of Leoben, Peter Tunner Str. 5, A-8700 Leoben, Austria; \\ Federica.Zaccarini@unileoben.ac.at \\ * Correspondence: biagioni@dst.unipi.it; Tel.: +39-50-221-5770 \\ Academic Editor: Thomas N. Kerestedjian \\ Received: 13 January 2016; Accepted: 14 February 2016; Published: 19 February 2016
}

\begin{abstract}
A crystal-chemical study of historical specimens as well as new ones belonging to the jordanite-geocronite series from the Pollone baryte + pyrite $\pm(\mathrm{Pb}-\mathrm{Zn}-\mathrm{Ag})$ ore deposit (Valdicastello Carducci, Apuan Alps, Tuscany, Italy) has been performed. These crystals were collected in quartz extension veins embedded in three different occurrences: (i) baryte + pyrite orebodies; (ii) schist layers interbedded between baryte + pyrite orebodies; and (iii) schists at the contact with pyrite-poor baryte orebodies. Electron-microprobe data indicated the occurrence of three distinct groups of compositions within the sample suite. These correspond to As-bearing geocronite, Sb-rich jordanite, and $\mathrm{Sb}$-bearing jordanite, with mean compositions $\mathrm{Pb}_{14} \mathrm{Sb}_{3.8} \mathrm{As}_{2.2} \mathrm{~S}_{23}, \mathrm{~Pb}_{14} \mathrm{Sb}_{2.9} \mathrm{As}_{3.1} \mathrm{~S}_{23}$, and $\mathrm{Pb}_{14} \mathrm{Sb}_{2.6} \mathrm{As}_{3.4} \mathrm{~S}_{23}$, respectively. Crystals representative of these different compositions have been investigated through single-crystal X-Ray diffraction studies and their crystal structures have been solved to $R_{1}=0.078,0.069$, and 0.033 , respectively. The unit-cell volume decreases passing through As-bearing geocronite $\left(V=2149.5(3) \AA^{3}\right)$ to Sb-bearing jordanite $\left(V=2132.3(3) \AA^{3}\right)$. The As-to-Sb substitution takes place preferentially at the $\mathrm{Sb} 4$ site; through the increasing of the $\mathrm{Sb}$ content, $\mathrm{Sb}$ can substitute As also at the As6 site. According to the structural study of the ore deposit, formation of jordanite-geocronite is subordinated to a late Alpine deformative $\mathrm{D}_{2}$ stage, which permitted in situ remobilization of preexisting sulfide ore in small quartz extension veins. Such a local recrystallization would explain the variability of the $\mathrm{As} /(\mathrm{As}+\mathrm{Sb})$ ratio of the members of the jordanite series, reflecting the heterogeneity of the orebody.
\end{abstract}

Keywords: jordanite; geocronite; lead; antimony; arsenic; Pollone mine; Apuan Alps; Italy

\section{Introduction}

The two isotypic minerals jordanite, $\mathrm{Pb}_{14}(\mathrm{As}, \mathrm{Sb})_{6} \mathrm{~S}_{23}$, and geocronite, $\mathrm{Pb}_{14}(\mathrm{Sb}, \mathrm{As})_{6} \mathrm{~S}_{23}$, are the phases having the most PbS-rich composition in the ternary system $\mathrm{PbS}-\mathrm{As}_{2} \mathrm{~S}_{3}-\mathrm{Sb}_{2} \mathrm{~S}_{3}$ [1], comprising 22 approved mineral species (Table 1). 
Table 1. Pb-(Sb/As) sulfosalts. Chemical formulae after the official IMA-CNMNC List of Minerals Name (updated November 2015). In bold, $\mathrm{Pb}-(\mathrm{Sb} / \mathrm{As})$ sulfosalts identified in the hydrothermal ores from Apuan Alps.

\begin{tabular}{cccc}
\hline Mineral & Chemical Formula & Mineral & Chemical Formula \\
\hline Baumhauerite & $\mathrm{Pb}_{12} \mathrm{As}_{16} \mathrm{~S}_{36}$ & Lopatkaite & $\mathrm{Pb}_{5} \mathrm{Sb}_{3} \mathrm{AsS}_{11}$ \\
Bernarlottiite & $\mathrm{Pb}_{6} \mathrm{As}_{5} \mathrm{Sb}_{3} \mathrm{~S}_{18}$ & Madocite & $\mathrm{Pb}_{19}\left(\mathrm{Sb}_{1} \mathrm{As}_{16} \mathrm{~S}_{43}\right.$ \\
Boulangerite & $\mathrm{Pb}_{5} \mathrm{Sb}_{4} \mathrm{~S}_{11}$ & Marumoite & $\mathrm{Pb}_{32} \mathrm{As}_{40} \mathrm{~S}_{92}$ \\
Dufrénoysite & $\mathrm{Pb}_{2} \mathrm{As}_{2} \mathrm{~S}_{5}$ & Plagionite & $\mathrm{Pb}_{5} \mathrm{Sb}_{8} \mathrm{~S}_{17}$ \\
Fülöppite & $\mathrm{Pb}_{3} \mathrm{Sb}_{8} \mathrm{~S}_{15}$ & Robinsonite & $\mathrm{Pb}_{4} \mathrm{Sb}_{6} \mathrm{~S}_{13}$ \\
Geocronite & $\mathrm{Pb}_{14}\left(\mathrm{Sb}_{1}, \mathrm{As}_{6} \mathrm{~S}_{23}\right.$ & Sartorite & $\mathrm{PbAs}_{2} \mathrm{~S}_{4}$ \\
Gratonite & $\mathrm{Pb}_{9} \mathrm{As}_{4} \mathrm{~S}_{15}$ & Semseyite & $\mathrm{Pb}_{9} \mathrm{Sb}_{8} \mathrm{~S}_{21}$ \\
Guettardite & $\mathrm{Pb}_{8}\left(\mathrm{Sb}_{0.56} \mathrm{As}_{0.44}\right)_{16} \mathrm{~S}_{32}$ & Tsugaruite & $\mathrm{Pb}_{4} \mathrm{As}_{2} \mathrm{~S}_{7}$ \\
Heteromorphite & $\mathrm{Pb}_{7} \mathrm{Sb}_{8} \mathrm{~S}_{19}$ & Twinnite & $\mathrm{Pb}_{(1}\left(\mathrm{Sb}_{0.63} \mathrm{As}_{0.37}\right)_{2} \mathrm{~S}_{4}$ \\
Jordanite & $\mathrm{Pb}_{14}\left(\mathrm{As}_{2} \mathrm{Sb}_{6} \mathrm{~S}_{23}\right.$ & Veenite & $\mathrm{Pb}_{2}\left(\mathrm{Sb}_{2} \mathrm{As}_{2} \mathrm{~S}_{5}\right.$ \\
Liveingite & $\mathrm{Pb}_{20} \mathrm{As}_{24} \mathrm{~S}_{56}$ & Zinkenite & $\mathrm{Pb}_{9} \mathrm{Sb}_{22} \mathrm{~S}_{42}$ \\
\hline
\end{tabular}

Geocronite and jordanite are widespread in several ore deposits, but only rarely occur as idiomorphic crystals, e.g., at Lengenbach, Binn Valley, Switzerland, where jordanite was first described [2], or at Valdicastello Carducci, Apuan Alps, Italy, where As-rich geocronite was reported [3].

The latter locality has been well-known since the mid-1840s for the occurrence of large and well-developed crystals of geocronite. After the very first contribution of the German mining engineer Thomas Kerndt [3], the specimens kept in the mineralogical collection of the University of Pisa were studied by few other authors $[4,5]$. These specimens were famous within the mineralogical community at the end of the 19th Century and, on the basis of their study, the isomorphism between geocronite and jordanite was proposed [6]. Solly wrote: "The only crystallographic determination of geocronite was made by Kerndt in 1845 from a rough dull crystal from Pietrasanta, Val di Castello, Tuscany. When I was at Pisa in May, 1899, G. D'Achiardi showed me two large fine crystals from the same locality which A. D'Achiardi had briefly described in 1873. They were found to exhibit the characteristic twin lamellae of jordanite" [6]. Later, the study of a specimen of microcrystalline geocronite in quartz showed an $(\mathrm{As} / \mathrm{Sb})$ atomic ratio close to one (or maybe with As slightly dominant over $\mathrm{Sb}$ ), on the basis of a semi-quantitative X-Ray fluorescence analysis [7]; during the same study, the following unit-cell parameters were refined: $a=9.009(5)$, $b=31.95(3), c=8.518(5) \AA, \beta=118.08(8)^{\circ}$ [7]. Finally, electron-microprobe data of geocronite from the Pollone mine were reported [8].

Notwithstanding these contributions, a modern mineralogical study of the specimens of geocronite from the Pollone mine was lacking. Consequently, in the framework of the study of lead-antimony sulfosalts from Apuan Alps as well as the characterization of the sulfide assemblages from the baryte + pyrite ore deposits from southern Apuan Alps, several samples belonging to the jordanite-geocronite series have been investigated and their occurrence has been accurately described.

\section{Geological Setting and Occurrences of Members of the Jordanite-Geocronite Series}

The geological setting of the Pollone mine (latitude $43^{\circ} 57^{\prime} 47^{\prime \prime} \mathrm{N}$; longitude $10^{\circ} 16^{\prime} 19^{\prime \prime} \mathrm{E}$ ), near the small hamlet of Valdicastello Carducci, Pietrasanta, Tuscany, Italy, has been described in previous papers by several authors (e.g., $[9,10])$. The ore deposit is hosted within a Paleozoic metavolcanic-metasedimentary sequence metamorphosed up to the greenschist facies during Alpine orogenesis. Estimates of $P-T$ conditions indicate that host rocks recorded metamorphic temperatures of about $350{ }^{\circ} \mathrm{C}$ with a pressure of $0.35 \mathrm{GPa}$; higher temperatures (around $450{ }^{\circ} \mathrm{C}$ ) were found for the mineralizing fluids [9]. The Pollone area is characterized by a pervasive, westward-dipping foliation $\left(S_{2}\right)$ attributed to the second deformative Alpine stage $D_{2}[9,10]$. $S_{2}$ almost totally overprinted an earlier $S_{1}$ foliation which is only preserved in microlithons and at the hinge of $D_{2}$ folds.

The orebodies at the Pollone mine have been classically subdivided on the basis of their geometric relationships with respect to the main $S_{2}$ foliation $[9,10]$ : (i) near-conformable baryte + pyrite \pm galena 
\pm sphalerite lenses/layers; and (ii) discordant baryte + pyrite \pm galena \pm sphalerite veins. However, all previous authors outlined the problematic interpretation of the "discordant" vein orebodies due to the limited accessibility of the old stopes (southeast zone: Ribasso, Rosina, and Preziosa stopes) where the main "veins" have been exploited. In the frame of this study, a detailed geological survey of these old stopes using speleological techniques was performed (Figure 1).

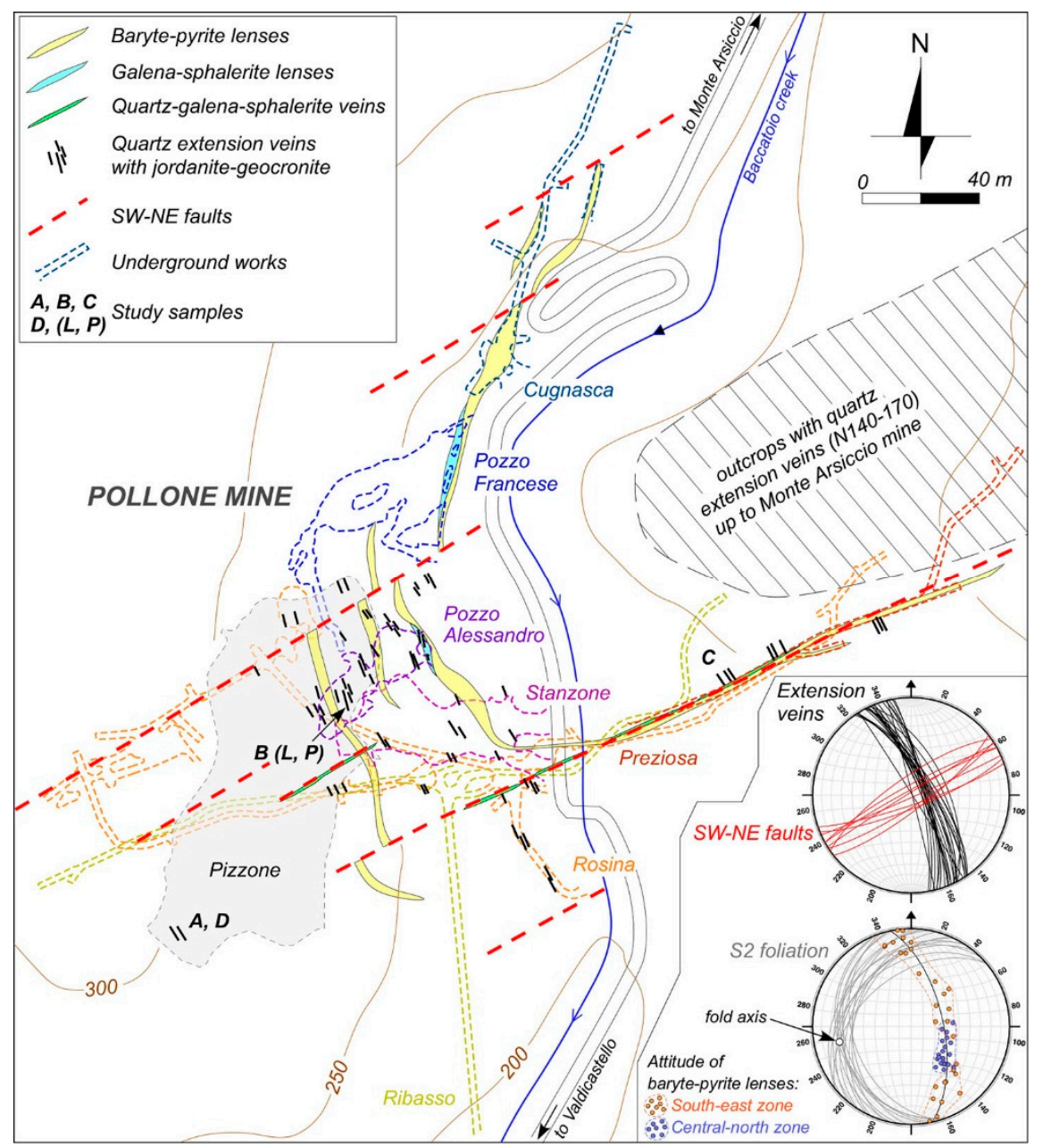

Figure 1. Schematic map of the Pollone mine, showing the main geological and structural features discussed in the text. Mining stopes and location of study samples are also reported.

Systematic observation and measurement of the main baryte + pyrite orebodies indicate that large baryte + pyrite veins do not exist at the Pollone mine. The large, NE-trending sub-vertical body exploited in the southeast zone is just the continuation of the near-conformable lenses exploited in the central-north zone (Pizzone, Pozzo Alessandro, Stanzone, Pozzo Francese, and Cugnasca stopes). From north to south, there is a continuous change in the attitude of the baryte + pyrite lenses, from dominantly west-dipping to progressively southward-dipping, which is coherent with the existence of a large syn- $\mathrm{D}_{2}$ recumbent fold (Figure 1; fold axis N258/27). In the southeast zone, the baryte + pyrite lenses are almost sub-vertical because the stopes were developed along the fold hinge. Here, the $S_{2}$ foliation is at high angle with the ore lenses and the earlier $S_{1}$ foliation, which is well preserved in host rocks. $S_{1}$ is parallel to the contacts between the ore lenses and the host rocks and to the baryte + pyrite banding in the orebody. On the contrary, the orebodies in the central-north zone are along the upper limb of the fold, and $S_{2}$ foliation is almost parallel to ore lenses, ore banding and $S_{1}$ foliation. Locally (Pozzo Alessandro and Pozzo Francese stopes, Figure 1), microcrystalline 
lenses/layers of galena + sphalerite are strictly associated to the main baryte + pyrite orebodies and interlayered with host rocks and baryte + pyrite ore.

A second important structural feature is represented by SW-NE sub-vertical/mid-angle faults, which can be followed from surface down to the lowest levels (Figure 1). They crosscut the orebodies producing several right-lateral offsets and locally controlling the formation of fault-parallel, SW-NE quartz lensoid veins with coarse-grained masses of galena, sphalerite, and sulfosalts. One of the biggest SW-NE faults developed in correspondence of the hinge of the $\mathrm{D}_{2}$ recumbent fold, interfering with the steepened baryte-pyrite orebodies. This interference produced a complex and ambiguous ore/structural pattern, which was responsible for the wrong interpretation of these orebodies in the past. Although very small in size, the SW-NE quartz-sulfide veins were actively exploited in ancient time (from Middle Age to early 20th Century), owing to the very high Ag content related to the relatively abundance of $\mathrm{Ag}$ sulfosalts included in galena [11].

Members of the jordanite-geocronite series have been collected in sub-vertical quartz \pm baryte \pm sulfides veins, trending N140-170 and embedded in the country rocks as well as, more rarely, in the orebodies (Figure 1). These veins clearly postdate the formation of the main orebodies, crosscutting at high angle the metamorphic foliations $\left(S_{2}\right.$ and $\left.S_{1}\right)$ and ore layering. They are extension veins, up to 2-3 $\mathrm{m}$ in length/height and ranging in thickness from few $\mathrm{mm}$ up to $60 \mathrm{~cm}$; they sometimes show an irregular sigmoidal shape (tension-gashes). A variety of infill pattern has been observed: from open fractures lined by druses of euhedral crystals, to partially filled veins with large axial cavities, up to massive veins with scattered small pockets. Quartz \pm baryte represent the early infill, while sulfides crystallized in a relatively later stage producing interstitial aggregates, veinlets and euhedral crystals in open spaces; albite and "adularia" are locally abundant in cavities. A preferential distribution of the extension veins is observed in the Pizzone-Pozzo Alessandro-Stanzone-Rosina-Preziosa stopes, especially in the overstepping domain between the two main SW-NE faults (Figure 1). The swarm of N140-170 veins can be traced eastward for at least $700 \mathrm{~m}$, well outside the Pollone deposit, defining a SW-NE belt up to the nearby Monte Arsiccio deposit.

The jordanite-geocronite specimens studied in this work, listed in Table 2, have been collected from three different occurrences (Figure 1):

(1) Extension veins hosted in baryte-pyrite orebodies;

(2) Extension veins hosted in schists interlayered between baryte-pyrite orebodies;

(3) Extension veins hosted in schists at contact with pyrite-poor baryte orebodies.

Table 2. Studied samples of members of the jordanite-geocronite series.

\begin{tabular}{ccc}
\hline Label & Description & Occurrence/Stope \\
\hline $\mathrm{A}$ & $\begin{array}{c}\text { Lead-gray, striated, prismatic crystals up to 5 mm in } \\
\text { length, from a pocket }\end{array}$ & Type-1/Pizzone \\
\hline $\mathrm{B}(\# 30)$ & Lead-gray crystals, up to 1 cm in size, from a pocket & Type 2/Pozzo Alessandro \\
\hline $\mathrm{C}(\# 31)$ & $\begin{array}{c}\text { Lead-gray crystals embedded in } \\
\text { quartz + baryte vein }\end{array}$ & Type-3/Preziosa \\
\hline $\mathrm{D}(\# 32)$ & Lead-gray compact veinlet & Type-1/Pizzone \\
\hline $\mathrm{L}$ & $\begin{array}{c}\text { Well-developed dipyramidal crystal. } \\
\text { Historical specimen \#14798 }\end{array}$ & Type-2 (?)/Unknown \\
\hline $\mathrm{P}$ & $\begin{array}{c}\text { Large deeply striated crystal. } \\
\text { Historical specimen \#14786 }\end{array}$ & Type-2 (?)/Unknown \\
\hline
\end{tabular}

Type-1 occurrence has been sampled in the Pizzone stope (samples A and D). Extension veins have limited thickness and are hosted by a baryte + pyrite lens dipping to west. In most cases they are represented by open fractures lined by crystals of baryte and quartz; baryte infill may dominate on quartz. These veins locally propagate into the schist host (sample D). Type- 1 is an uncommon occurrence because at Pollone most of the extension veins developed into the schists. In the same 
occurrence, several Sb-As sulfosalts have been identified: parasterryite, proustite-pyrargyrite, sterryite, Ag-rich tennantite, and xanthoconite [12].

Type-2 represents the most common occurrence for jordanite-geocronite specimens at the Pollone mine. Quartz extension veins are hosted in schist layers (1-5 m thick) interbedded between multiple baryte + pyrite lenses, although rarely they propagate into the ore bodies. They are mainly concentrated in the overstepping domain between the two main SW-NE faults (Pizzone-Pozzo Alessandro-Stanzone-Rosina stopes). Type-2 occurrence provides the largest veins, up to several meters in length/height and up to $60 \mathrm{~cm}$ thick. Veins are predominantly filled by coarse-grained massive quartz but large cavities lined by beautiful crystals of smoky quartz and baryte are quite common. The largest masses of jordanite-geocronite (up to several $\mathrm{kg}$ ) as well as the best idiomorphic crystals (up to $10 \mathrm{~cm}$ in length) come from these veins. Jordanite-geocronite is usually associated with sphalerite and tennantite $[\mathrm{As} /(\mathrm{As}+\mathrm{Sb})$ atomic ratio $=0.94$, on the basis on single-crystal X-Ray diffraction study]. Type-2 occurrence has been sampled at the Pozzo Alessandro stope (sample B). Probably, the two historical specimens kept in the mineralogical collections of the Museo di Storia Naturale of the University of Pisa (samples L and P; Figure 2) were found in Type-2 occurrence (possibly from the Pozzo Alessandro stope, see below).

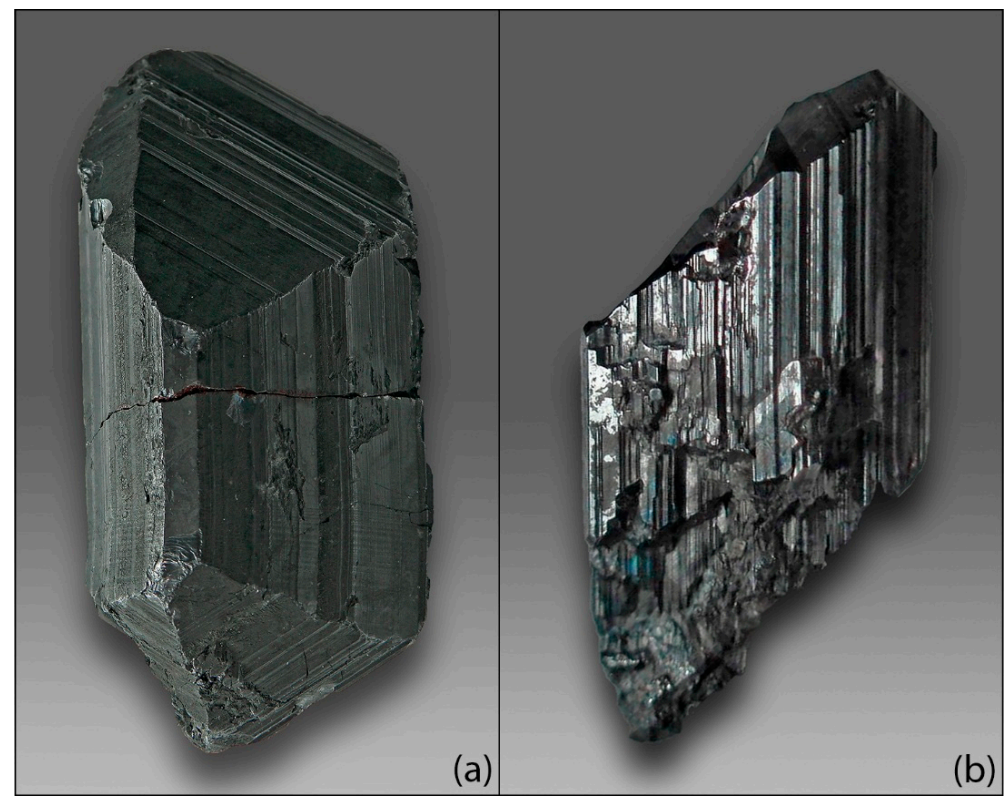

Figure 2. Crystals of members of the jordanite-geocronite series from the Pollone mine: (a) Historical specimen \#14798, Natural History Museum, University of Pisa. Crystal size: $12 \mathrm{~cm} \times 7 \mathrm{~cm}$; and (b) Tabular deeply striated crystal ( $8 \mathrm{~mm}$ in size) from Type-1 occurrence. Private collection.

Type-3 occurrence has been sampled in the Preziosa stope (sample C). Like for Type-1, the extension veins have a limited extent. They are hosted in the schist at the footwall of the steepened baryte-pyrite lens, which was reworked by late SW-NE faults and overprinted by SW-NE quartz-sulfide lensoid veins. The infill of the extension veins is locally in continuity with quartz of the SW-NE veins. In this zone, pyrite is distinctly less abundant than in the central-north zone of the Pollone deposit.

\section{Chemical Data}

Two sets of quantitative chemical analyses were carried out. Samples A to D were analyzed using a Superprobe JEOL JXA 8200 electron-microprobe (Eugen F. Stumpfl laboratory, Leoben University, Leoben, Austria). The operating conditions were: accelerating voltage $20 \mathrm{kV}$, beam current $10 \mathrm{nA}$, beam size $\approx 1 \mu \mathrm{m}$. Counting times were $30 \mathrm{~s}$ on the peak and $15 \mathrm{~s}$ on the right and left backgrounds. 
Standards (element, emission line) were: pyrite $(\mathrm{S} K \alpha)$, galena $(\mathrm{Pb} M \alpha)$, stibnite $(\mathrm{Sb} L \alpha)$, GaAs $(\mathrm{As} L \alpha)$, and $\mathrm{Bi}_{2} \mathrm{Te}_{3}(\mathrm{Bi} M \alpha)$.

Quantitative chemical analyses of the historical samples L and P were carried out using a CAMECA SX50 electron-microprobe (BRGM-CNRS-University common laboratory, Orléans, France). The operating conditions were: accelerating voltage $20 \mathrm{kV}$, beam current $20 \mathrm{nA}$, beam size $\approx 1 \mu \mathrm{m}$. Standards (element, emission line, counting time) are: $\mathrm{PbS}(\mathrm{Pb} M \alpha, 20$ s), stibnite ( $\mathrm{Sb} L \alpha, 20$ s), pyrite ( $\mathrm{S} K \alpha, 20 \mathrm{~s}), \mathrm{AsGa}(\mathrm{As} L \alpha, 30 \mathrm{~s})$, and vanadinite $(\mathrm{Cl} K \alpha, 60 \mathrm{~s})$.

The studied grains were very homogeneous. Chemical data are given in Table 3.

Table 3. Chemical data (in wt \%) and chemical formulae (on the basis of $\Sigma M e=20$ atoms per formula unit, $a p f u$ ) for members of the jordanite-geocronite series. Labels as in Table 2.

\begin{tabular}{|c|c|c|c|c|c|c|c|c|c|c|c|c|}
\hline \multirow{2}{*}{ Element } & \multicolumn{2}{|c|}{$\mathrm{A}(n=20)$} & \multicolumn{2}{|c|}{ B $(n=20)$} & \multicolumn{2}{|c|}{$C(n=20)$} & \multicolumn{2}{|c|}{$\mathrm{D}(n=10)$} & \multicolumn{2}{|c|}{$\mathrm{L}(n=6)$} & \multicolumn{2}{|c|}{$\mathrm{P}(n=4)$} \\
\hline & Mean & $\Sigma$ & Mean & $\Sigma$ & Mean & $\Sigma$ & Mean & $\Sigma$ & Mean & $\Sigma$ & Mean & $\Sigma$ \\
\hline $\mathrm{Pb}$ & 67.66 & 0.34 & 68.73 & 0.27 & 67.42 & 0.28 & 68.66 & 0.20 & 68.66 & 0.31 & 68.89 & 0.20 \\
\hline As & 6.15 & 0.07 & 5.34 & 0.08 & 3.90 & 0.06 & 5.88 & 0.08 & 5.54 & 0.04 & 5.65 & 0.04 \\
\hline $\mathrm{Sb}$ & 7.44 & 0.07 & 8.35 & 0.12 & 11.01 & 0.15 & 7.21 & 0.19 & 8.27 & 0.06 & 8.20 & 0.06 \\
\hline $\mathrm{Bi}$ & 0.33 & 0.05 & 0.35 & 0.03 & 0.47 & 0.03 & 0.38 & 0.05 & - & - & - & - \\
\hline S & 17.51 & 0.12 & 17.50 & 0.15 & 17.55 & 0.16 & 17.80 & 0.11 & 17.68 & 0.06 & 17.64 & 0.13 \\
\hline $\mathrm{Cl}$ & - & - & - & - & - & - & - & - & 0.03 & 0.02 & 0.02 & 0.01 \\
\hline Total & 99.08 & 0.42 & 100.26 & 0.33 & 100.35 & 0.37 & 99.93 & 0.29 & 100.18 & 0.33 & 100.40 & 0.30 \\
\hline \multicolumn{13}{|l|}{$a p f u$} \\
\hline $\mathrm{Pb}$ & 13.86 & 0.04 & 14.02 & 0.05 & 13.84 & 0.04 & 14.07 & 0.07 & 14.01 & 0.09 & 13.98 & 0.06 \\
\hline As & 3.49 & 0.03 & 3.01 & 0.04 & 2.21 & 0.03 & 3.33 & 0.03 & 3.13 & 0.02 & 3.17 & 0.01 \\
\hline $\mathrm{Sb}$ & 2.59 & 0.02 & 2.90 & 0.03 & 3.85 & 0.04 & 2.52 & 0.06 & 2.87 & 0.02 & 2.83 & 0.01 \\
\hline $\mathrm{Bi}$ & 0.07 & 0.01 & 0.07 & 0.01 & 0.10 & 0.01 & 0.08 & 0.01 & - & - & - & - \\
\hline S & 23.17 & 0.20 & 23.06 & 0.24 & 23.28 & 0.24 & 23.57 & 0.20 & 23.32 & 0.11 & 23.13 & 0.27 \\
\hline $\mathrm{Cl}$ & - & - & - & - & - & - & - & - & 0.03 & 0.02 & 0.02 & 0.01 \\
\hline$E v(\%)$ & -0.4 & 0.9 & -0.3 & 1.0 & -0.9 & 1.0 & -2.6 & 0.9 & -1.4 & 0.5 & -0.7 & 0.9 \\
\hline $\mathrm{As} /(\mathrm{As}+\mathrm{Sb}+\mathrm{Bi})$ & 0.567 & 0.003 & 0.504 & 0.004 & 0.360 & 0.005 & 0.562 & 0.007 & 0.521 & 0.002 & 0.528 & 0.001 \\
\hline
\end{tabular}

Note: $\operatorname{Ev}(\%)=[\operatorname{\Sigma val}(+)-\Sigma v a l(-)] \times 100 / \Sigma v a l(-)]$.

The $\mathrm{As} /(\mathrm{As}+\mathrm{Sb})$ atomic ratio ranges between 0.36 and 0.57 . Figure 3 shows the chemical variability of the members of the jordanite-geocronite series from the Pollone mine.

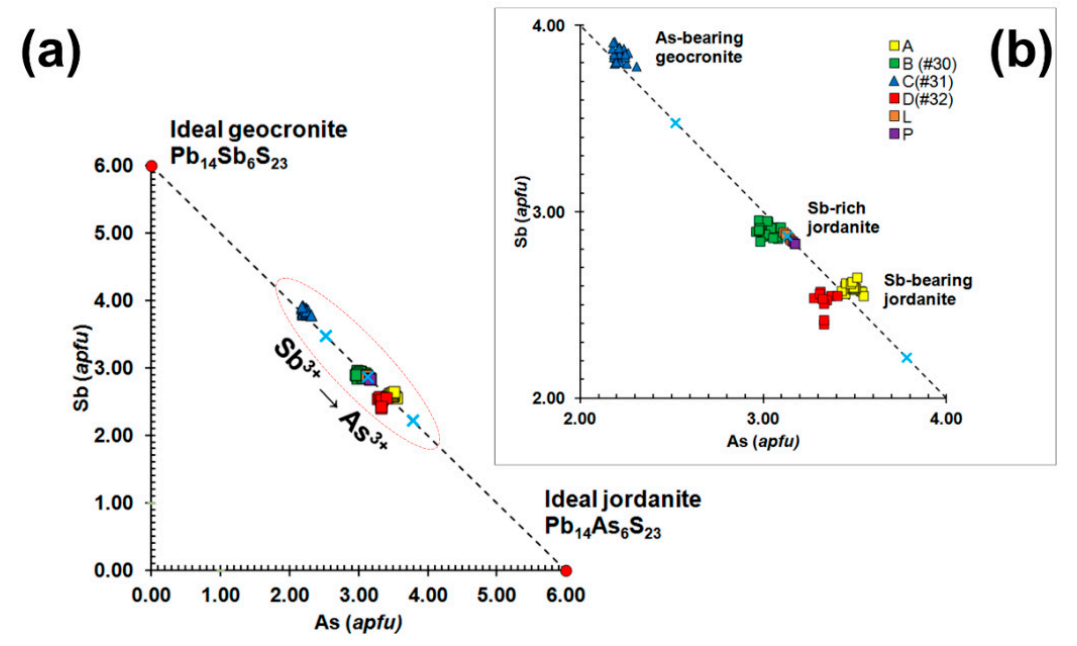

Figure 3. Chemical variability of jordanite-geocronite samples from the Pollone mine: (a) The chemical range of the studied specimens in the framework of the jordanite-geocronite series; and (b) A closer view of this range, showing the three different chemical compositions. Labels as in Table 2. Light blue crosses indicate the compositions obtained through structure refinement. 
Samples A and D, collected in the Pizzone stope, correspond to Sb-bearing jordanite, whereas sample C, from the Preziosa stope, is an As-bearing geocronite. Finally, sample B, collected in the Pozzo Alessandro stope, displays a chemical composition close to the historical specimens $\mathrm{L}$ and $\mathrm{P}$, in agreement with the hypothesis of the finding of these huge crystals from this stope. These samples are close to the $50 \%$ limit between jordanite and geocronite. Actually, they can be classified as $\mathrm{Sb}$-rich jordanite. These three groups have mean compositions close to $\mathrm{Pb}_{14} \mathrm{Sb}_{2.6} \mathrm{As}_{3.4} \mathrm{~S}_{23}$ (A and D), $\mathrm{Pb}_{14} \mathrm{Sb}_{3.8} \mathrm{As}_{2.2} \mathrm{~S}_{23}(\mathrm{C})$, and $\mathrm{Pb}_{14} \mathrm{Sb}_{2.9} \mathrm{As}_{3.1} \mathrm{~S}_{23}(\mathrm{~B}, \mathrm{~L}$ and $\mathrm{P})$.

\section{Crystallography}

Three crystals of members of the jordanite-geocronite series occurring at the Pollone mine, i.e., Sb-bearing jordanite, Sb-rich jordanite, and As-bearing geocronite, were studied through single-crystal X-Ray diffraction.

Intensity data were collected using a Bruker Smart Breeze diffractometer equipped with an air-cooled $\mathrm{CCD}$ detector and graphite-monochromatized Mo $K \alpha$ radiation. The detector to crystal distance was $50 \mathrm{~mm}$. The data were corrected for the Lorentz, polarization, absorption, and background effects using the package of software Apex2 [13]. In all cases, the statistical tests on the distribution of the $|E|$ values and the systematic absences agreed with the centric space group $P 2_{1} / m$. The crystal structures were refined using Shelxl-97 [14] starting from the atomic coordinates and site occupancies given in [15]. Scattering curves for neutral atoms were taken from the International Tables for Crystallography [16]. Details of data collection and structure refinements are given in Table 4. Atomic coordinates, displacement parameters, and bond distances are reported in the Crystallographic Information Files available as Supplementary Material.

Table 4. Crystal and experimental details for members of the jordanite-geocronite series from the Pollone mine.

\begin{tabular}{|c|c|c|c|}
\hline Crystal Data & Sb-Bearing Jordanite & Sb-Rich Jordanite & As-Bearing Geocronite \\
\hline X-Ray formula & $\mathrm{Pb}_{14}\left(\mathrm{As}_{3.78} \mathrm{Sb}_{2.22}\right) \mathrm{S}_{23}$ & $\mathrm{~Pb}_{14}\left(\mathrm{As}_{3.20} \mathrm{Sb}_{2.80}\right) \mathrm{S}_{23}$ & $\mathrm{~Pb}_{14}\left(\mathrm{Sb}_{3.46} \mathrm{As}_{2.54}\right) \mathrm{S}_{23}$ \\
\hline Crystal size $\left(\mathrm{mm}^{3}\right)$ & $0.160 \times 0.065 \times 0.045$ & $0.250 \times 0.150 \times 0.150$ & $0.150 \times 0.140 \times 0.040$ \\
\hline Cell setting, space group & & Monoclinic, $P 2_{1} / m$ & \\
\hline$a(\AA)$ & $8.9338(8)$ & $8.9554(3)$ & $8.9720(6)$ \\
\hline$b(\AA)$ & $31.891(3)$ & $31.9228(11)$ & $31.9535(22)$ \\
\hline$c(\AA)$ & $8.4720(8)$ & $8.4937(3)$ & $8.4888(6)$ \\
\hline$\beta\left(^{\circ}\right)$ & $117.943(1)$ & $117.981(1)$ & $117.964(4)$ \\
\hline$V\left(\AA^{3}\right)$ & $2132.3(3)$ & $2144.3(1)$ & $2149.5(3)$ \\
\hline $\mathrm{Z}$ & 2 & 2 & 2 \\
\hline Data collection and refinement & Sb-bearing jordanite & Sb-rich jordanite & As-bearing geocronite \\
\hline Radiation, wavelength $(\AA)$ & & Mo $K \alpha, \lambda=0.71073$ & \\
\hline Temperature (K) & & 293 & \\
\hline $2 \theta_{\max }\left({ }^{\circ}\right)$ & 65.07 & 65.14 & 65.00 \\
\hline Measured reflections & 27,684 & 26,879 & 29,406 \\
\hline Unique reflections & 7756 & 7674 & 7852 \\
\hline Reflections with $F_{\mathrm{o}}>4 \sigma\left(F_{\mathrm{o}}\right)$ & 6231 & 5394 & 5751 \\
\hline$R_{\text {int }}$ & 0.0350 & 0.0672 & 0.0697 \\
\hline \multirow[t]{2}{*}{$R \sigma$} & 0.0327 & 0.0707 & 0.0640 \\
\hline & $-12 \leqslant h \leqslant 13$ & $-13 \leqslant h \leqslant 13$ & $-13 \leqslant h \leqslant 13$ \\
\hline \multirow[t]{2}{*}{ Range of $h, k, l$} & $-42 \leqslant k \leqslant 48$ & $-48 \leqslant k \leqslant 45$ & $-47 \leqslant k \leqslant 48$ \\
\hline & $-12 \leqslant l \leqslant 12$ & $-12 \leqslant l \leqslant 12$ & $-12 \leqslant l \leqslant 12$ \\
\hline$R\left[F_{\mathrm{o}}>4 \sigma\left(F_{\mathrm{o}}\right)\right]$ & 0.0332 & 0.0687 & 0.0782 \\
\hline$R$ (all data) & 0.0467 & 0.0970 & 0.1053 \\
\hline $\mathrm{w} R\left(\right.$ on $\left.F^{2}\right)$ & 0.0777 & 0.1840 & 0.2012 \\
\hline GooF & 1.048 & 1.094 & 1.133 \\
\hline Number of l.s. parameters & 216 & 217 & 216 \\
\hline Maximum and minimum & 4.23 (at $0.73 \AA$ from $\mathrm{Pb} 9)$ & 5.66 (at $0.85 \AA$ from $\mathrm{Pb} 8$ ) & 8.15 (at $0.92 \AA$ from $\mathrm{Pb} 12$ ) \\
\hline residuals $\left(e / \AA^{3}\right)$ & -3.83 (at $0.50 \AA$ from $\mathrm{Pb} 12$ ) & -5.85 (at $0.75 \AA$ from $\mathrm{Pb} 3$ ) & -4.89 (at $0.76 \AA$ from $\mathrm{Pb} 1$ ) \\
\hline
\end{tabular}




\section{Crystal Structure Description}

The general features of the crystal structure of members of the jordanite-geocronite series (Figure 4) from the Pollone mine agree with the previous structure determinations ([15,17]).

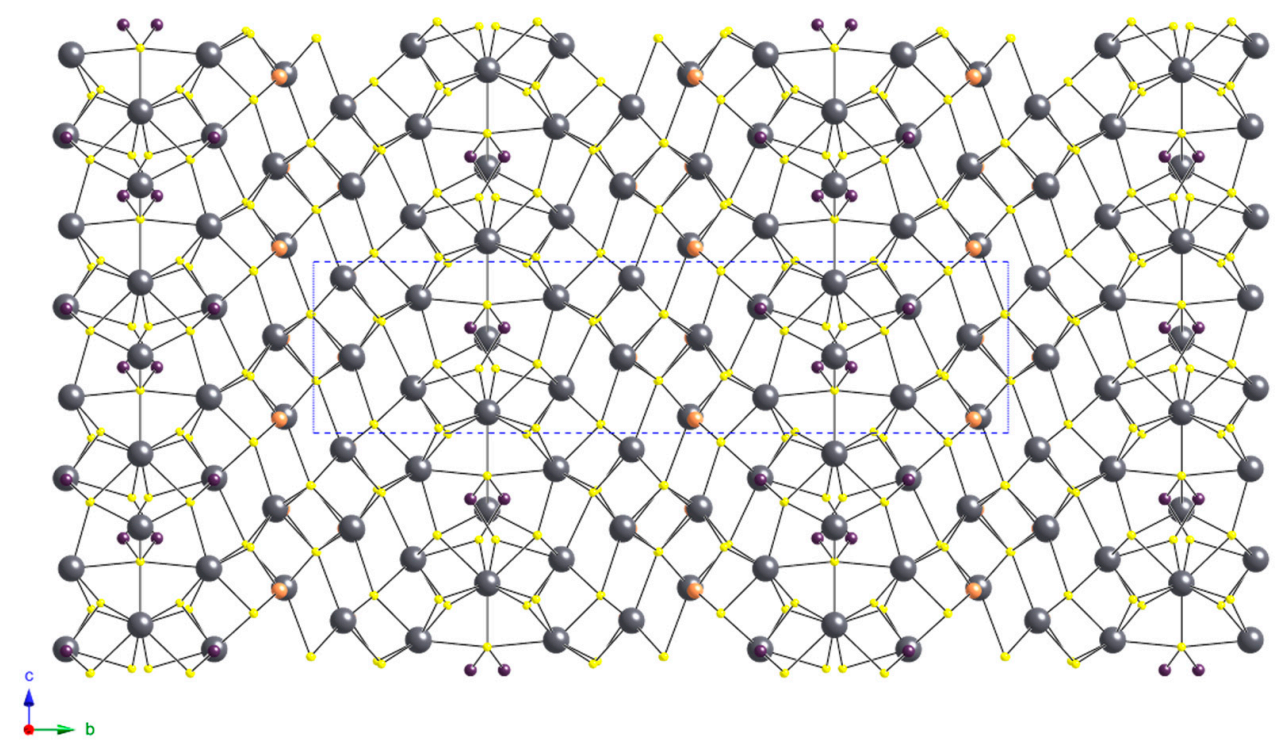

Figure 4. Crystal structure of members of the jordanite-geocronite series. Circles: lead grey $=\mathrm{Pb}$ sites; orange $=\mathrm{Sb}$ and $(\mathrm{Sb}, \mathrm{As})$ sites; violet $=\mathrm{As}$ and $(\mathrm{As}, \mathrm{Sb})$ sites; yellow $=\mathrm{S}$ sites .

Jordanite and geocronite are the $N=4$ members of the jordanite homologous series [18]. Following the modular description given by [19] for the $N=3$ homologue kirkiite, the crystal structure of jordanite can be described in two ways. Indeed, it can be considered as formed by the stacking of four distorted octahedral layers alternating with prismatic layers, sharing sulfur atoms along their boundaries, or, alternatively, it can be described in terms of (111) slabs of distorted PbS archetype or (210) slabs of SnS archetype. These slabs are mirror-twinned on (010) of the lattice, corresponding to the boundary layer of trigonal prisms in the polyhedral description.

Twelve cation and thirteen anion sites occur in the crystal structure of jordanite and geocronite (Figure 5).

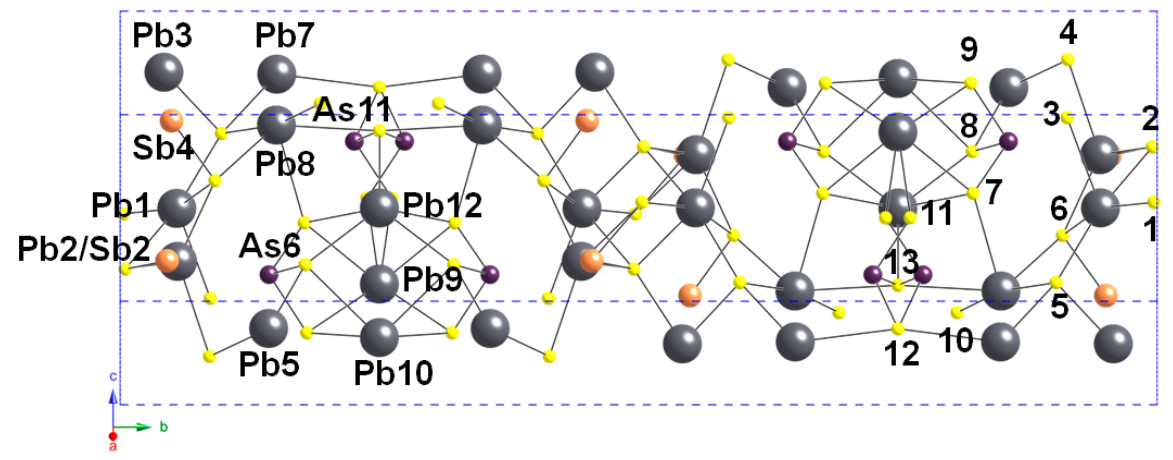

Figure 5. Unit-cell content of the members of the jordanite-geocronite series. Numbers without specification refer to $\mathrm{S}$ sites. Same symbols as in Figure 4 .

Table 5 shows a comparison between site occupancies and bond distances in metal sites in the three refined crystal structures.

Pure $\mathrm{Pb}$ sites have coordination number ranging from VI to VIII. $\mathrm{Pb} 1$ and $\mathrm{Pb} 3$ have a distorted octahedral coordination, with average bond distances ranging between 2.99 and $3.02 \AA$, in agreement 
with previous results $[15,17] . \mathrm{Pb} 5, \mathrm{~Pb} 7$, and $\mathrm{Pb} 8$ are seven-fold coordinated, whereas $\mathrm{Pb} 9$ and $\mathrm{Pb} 10$ have a bicapped trigonal prismatic coordination. A trigonal prismatic coordination characterizes the $\mathrm{Pb} 12$ site; two additional longer bonds at $\approx 3.95 \AA$ A complete its coordination sphere.

Table 5. Site occupation factors (s.o.f.) and average bond distances (in $\AA$ ) for metal sites in members of the jordanite-geocronite series from the Pollone mine.

\begin{tabular}{|c|c|c|c|c|c|c|}
\hline \multirow{2}{*}{ Site } & \multicolumn{2}{|c|}{ Sb-Bearing Jordanite } & \multicolumn{2}{|c|}{ Sb-Rich Jordanite } & \multicolumn{2}{|c|}{ As-Bearing Geocronite } \\
\hline & s.o.f. & $<M e-\mathrm{S}\rangle$ & s.o.f. & $\langle\mathrm{Me}-\mathrm{S}\rangle$ & s.o.f. & $<M e-\mathrm{S}>$ \\
\hline $\mathrm{Pb} 1$ & $\mathrm{~Pb}_{1.00}$ & 2.993 & $\mathrm{~Pb}_{1.00}$ & 2.996 & $\mathrm{~Pb}_{1.00}$ & 2.997 \\
\hline $\mathrm{Pb} 2 \mathrm{a} / \mathrm{Sb} 2 \mathrm{~b}$ & $\mathrm{~Pb}_{0.50} \mathrm{Sb}_{0.50}$ & $2.928 / 2.576$ & $\mathrm{~Pb}_{0.50} \mathrm{Sb}_{0.50}$ & $2.932 / 2.583$ & $\mathrm{~Pb}_{0.50} \mathrm{Sb}_{0.50}$ & $2.933 / 2.588$ \\
\hline $\mathrm{Pb} 3$ & $\mathrm{~Pb}_{1.00}$ & 3.011 & $\mathrm{~Pb}_{1.00}$ & 3.016 & $\mathrm{~Pb}_{1.00}$ & 3.014 \\
\hline $\mathrm{Sb} 4$ & $\mathrm{Sb}_{0.61(1)} \mathrm{As}_{0.39(1)}$ & 2.407 & $\mathrm{Sb}_{0.84(2)} \mathrm{As}_{0.16(2)}$ & 2.448 & $\mathrm{Sb}_{0.98(2)} \mathrm{As}_{0.02(2)}$ & 2.464 \\
\hline Pb5 & $\mathrm{Pb}_{1.00}$ & 3.047 & $\mathrm{~Pb}_{1.00}$ & 3.053 & $\mathrm{~Pb}_{1.00}$ & 3.054 \\
\hline As6 & $\mathrm{As}_{1.00}$ & 2.253 & $\mathrm{As}_{0.94(2)} \mathrm{Sb}_{0.06(2)}$ & 2.263 & $\mathrm{As}_{0.75(2)} \mathrm{Sb}_{0.25(2)}$ & 2.296 \\
\hline $\mathrm{Pb} 7$ & $\mathrm{~Pb}_{1.00}$ & 3.034 & $\mathrm{~Pb}_{1.00}$ & 3.037 & $\mathrm{~Pb}_{1.00}$ & 3.039 \\
\hline $\mathrm{Pb} 8$ & $\mathrm{~Pb}_{1.00}$ & 3.028 & $\mathrm{~Pb}_{1.00}$ & 3.032 & $\mathrm{~Pb}_{1.00}$ & 3.035 \\
\hline $\mathrm{Pb} 9$ & $\mathrm{~Pb}_{0.50}$ & 3.074 & $\mathrm{~Pb}_{0.50}$ & 3.073 & $\mathrm{~Pb}_{0.50}$ & 3.078 \\
\hline $\mathrm{Pb} 10$ & $\mathrm{~Pb}_{0.50}$ & 3.075 & $\mathrm{~Pb}_{0.50}$ & 3.079 & $\mathrm{~Pb}_{0.50}$ & 3.079 \\
\hline As11 & $\mathrm{As}_{0.50}$ & 2.211 & $\mathrm{As}_{0.50}$ & 2.221 & $\mathrm{As}_{0.50}$ & 2.225 \\
\hline $\mathrm{Pb} 12$ & $\mathrm{~Pb}_{0.50}$ & 3.023 & $\mathrm{~Pb}_{0.50}$ & 3.023 & $\mathrm{~Pb}_{0.50}$ & 3.017 \\
\hline
\end{tabular}

The $\mathrm{Me}^{3+}$ metals are hosted at four positions, i.e., Sb4, As6, As11, and at the split position Sb2. Taking into account the shortest (= strongest) bonds, i.e., Me-S distances shorter than $2.70 \AA$, these sites display a trigonal pyramidal coordination, with Me occupying the apex of the pyramid. The coordination sphere is completed by three additional longer bonds. $\mathrm{Sb} 4$ is a mixed (Sb,As) site in all three refined structures, with average $\langle\mathrm{Sb}-\mathrm{S}\rangle$ distance progressively increasing from 2.407 to $2.464 \AA$, passing from Sb-bearing jordanite to As-bearing geocronite. In jordanite from Lengenbach [15], the average bond distance at this site is $2.296 \AA$, whereas in geocronite it is $2.49 \AA$ [17]. As6 site is a pure As site in $\mathrm{Sb}$-bearing jordanite, whereas it is progressively enriched in $\mathrm{Sb}$ passing from As-rich jordanite to As-bearing geocronite. At the same time, the average $<A s-S>$ distance increases from 2.253 to $2.296 \AA$. As6 was refined as a pure As site in both jordanite and geocronite $[15,17]$. On the contrary, the refinements reported in this study suggest that the increasing $\mathrm{Sb}$ content from jordanite to geocronite is accompanied by the complete filling of Sb4 by antimony and the progressive substitution of As by Sb at the As6 site. According to [17], Sb should be hosted at the As11 site (Sb11 in [17], with site occupancy $S_{0.75} \mathrm{As}_{0.25}$ ) but the data reported in our study do not support this hypothesis. Indeed, the half occupied As11 is a pure As site, as suggested by the refined electron density and the average $<M e-S>$ distance. A possible limited substitution of As by $\mathrm{Sb}$ could be suggested by the slight increase of the average $<M e-S>$ distance passing from $\mathrm{Sb}$-bearing jordanite to As-bearing geocronite, as well as the small decrease of the equivalent isotropic displacement parameter (from 0.014 to $0.010 \AA^{2}$ ). In addition, the preferential occurrence of As at the site close to mirror plane in the crystal structure of jordanite homologues agrees with the crystal structure of kirkiite [19] as well as in a new $N=3.5$ homologue of jordanite under study.

Finally, a split $(\mathrm{Pb} / \mathrm{Sb}) 2$ position occurs. Both sub-positions $\mathrm{Pb} 2$ and $\mathrm{Sb} 2$ have a distorted octahedral coordination, with three relatively short distances (mean 2.763 and $2.576 \AA$ for the $\mathrm{Pb} 2$ and Sb2 sub-positions, respectively) and three relatively longer contacts (mean 3.093 and $3.22 \AA$, for $\mathrm{Pb} 2$ and Sb2, respectively).

\section{Discussion}

\subsection{Crystal-Chemistry of the Jordanite-Geocronite Isotypic Series from the Pollone Mine}

In addition to the chemical analyses given in Table 3, previous authors $[3,4,8]$ reported chemical data of geocronite from the Pollone mine. 
The oldest data were given in [3] and they can be considered reliable, with only a small $\mathrm{Pb}$ deficit and a small $\mathrm{S}$ excess $[E v(\%)=-0.9]$; the studied sample corresponds to an As-bearing geocronite, with empirical formula $\mathrm{Pb}_{13.85}\left(\mathrm{Sb}_{3.43} \mathrm{As}_{2.72}\right)_{\Sigma 6.15} \mathrm{~S}_{23.29}$. Such a crystal had a composition similar to that of the As-bearing geocronite from the Preziosa stope studied in this work. On the contrary, later chemical analyses given in [4] are of poor quality, showing significant $\mathrm{Pb}$ and $\mathrm{S}$ excesses. The only available electron-microprobe data were reported by [8]; these authors studied samples associated with a member of the tetrahedrite series tentatively identified as freibergite and with an acicular sulfosalt indicated as owyheeite. Unfortunately, three out of the four spot analyses gave an increasing $\mathrm{S}$ deficit. However, the As $/(\mathrm{As}+\mathrm{Sb})$ atomic ratio ranges between 0.34 and 0.37 and consequently the studied material can be classified as geocronite. As a matter of fact, all old available chemical data agrees with the occurrence of geocronite from the Pollone mine. The only possible occurrence of jordanite was detected (but not correctly identified) by [7], on the basis of semi-quantitative X-Ray fluorescence analyses, showing that As could be slightly dominant over $\mathrm{Sb}$ (i.e., Sb-rich jordanite).

New chemical and crystallographic data confirm the occurrence of members of the jordanite-geocronite isotypic series at the Pollone mine. They show a wide range of chemical variability. Type- 1 occurrence, sampled at the Pizzone stope, seems to be enriched in As with respect to quartz extension veins from Pozzo Alessandro (Type-2) and Preziosa stopes (Type-3), where increasing amount of Sb occurs. This statement seems to be confirmed by the association of Sb-bearing jordanite from the Pizzone stope with complex Sb-As sulfosalts (e.g., twinnite, As-bearing zinkenite, sterryite, parasterryite, carducciite, and polloneite $[12,20,21]$ ) and Ag sulfosalts (Ag-rich tennantite, proustite, and xanthoconite [12]). On the contrary, the Preziosa stope is characterized by the occurrence of some Sb-rich sulfosalts, like diaphorite and pyrargyrite [11], agreeing with the presence of As-bearing geocronite instead of its arsenic isotype.

It is worth noting the good, yet qualitative, correlation between the amount of pyrite in the host rocks surrounding the veins and the $\mathrm{As} /(\mathrm{As}+\mathrm{Sb})$ ratio of jordanite-geocronite. Sb-bearing jordanite (Type-1 occurrence from Pizzone stope) has been found in veins directly hosted by orebodies, Sb-rich jordanite (Type-2 occurrence from Pozzo Alessandro stope) was collected in schist-hosted veins near baryte + pyrite ores, while As-rich geocronite was found only in the relatively pyrite-poor setting of Preziosa stope (Type-3 occurrence; schist-hosted veins). Availability of antimony, especially during the late-stages of crystallization, is a common character of almost all the ore deposits in Apuan Alps (e.g., [22]). What still needs to be explained is the anomalous As-rich composition of sulfosalts from the central-north zone of Pollone deposit. A relatively high $f\left(\mathrm{~S}_{2}\right)$ may promote the sulfidation of arsenic (acting as an anion in As-bearing pyrite and arsenopyrite) to $\mathrm{As}^{3+}$ in jordanite-geocronite as well as in other sulfosalts. During the late evolution of Pollone ore deposit, the recrystallization of the baryte-pyrite ore $[8,10]$ could have favoured mobilization of arsenic under high $f\left(\mathrm{~S}_{2}\right)$ conditions and its sulfidation to $\mathrm{As}^{3+}$. We suggest that this effect reached a maximum in pyrite-rich environments (Type-1 occurrence) while it was less effective in Type-2 and Type- 3 occurrences where the pyrite component is progressively lower. A temporary increase in $f\left(\mathrm{~S}_{2}\right)$ is a common character of the early stage of cooling paths in many fossil hydrothermal systems (e.g., porphyry copper, polymetallic veins, high-sulfidation epithermal; [23]), before their $T$ and $f\left(\mathrm{~S}_{2}\right)$ definitely decrease following the typical Barton's ore-forming "Main line" [24].

A more detailed knowledge of the sulfide assemblages at the Pollone mine is mandatory to confirm and fully describe their suggested As-Sb heterogeneity at the orebody scale and the inferred genetic mechanism.

\subsection{Definition of Jordanite and Geocronite}

As for other sulfosalts, the first descriptions of the members of the jordanite-geocronite series were rather confusing. Geocronite was first described from the Sala mine, Västmanland, Sweden [25,26]. In the original description, the $\mathrm{As} /(\mathrm{As}+\mathrm{Sb})$ atomic ratio was 0.44 . In the same years, a lead-antimony sulfosalt was described from the Mérédo deposit, Spain [27], whereas kilbrickenite was described from 
the Kilbricken mine, County Clare, Ireland, by [28] who ignore the Swedish occurrence of geocronite. Later, As-free geocronite described by [27] was named schulzite [29]. Kilbrickenite was considered as a variety of geocronite in the earlier editions of Dana's "System of Mineralogy" or it was elevated to the dignity of separate mineral species by other authors [30]. As a matter of fact, in the mineralogical literature of the half of the 19th Century there was a lot of confusion about the status of these minerals; for example, geocronite was considered as an arsenian variety of schulzite [31]. Finally, the Sb-free analogue of geocronite, namely jordanite, was described from the Lengenbach quarry, Switzerland [2]. Consequently, at the end of the 19th Century, four mineral species have been described: geocronite, schulzite, kilbrickenite, and jordanite. The similarity between geocronite and jordanite was recognized on the basis of morphological features [6] and later confirmed through X-ray diffraction studies [32]. The identity of kilbrickenite with geocronite was established by [31], studying the type material.

The crystal structure of jordanite and geocronite were solved by [15] and [17], respectively. According to [17], geocronite was defined as the Sb-bearing analogue of jordanite, with composition $\mathrm{Pb}_{14}\left(\mathrm{As}_{2+x} \mathrm{Sb}_{4-x}\right) \mathrm{S}_{23}(0 \leqslant x<4)$. Jordanite was defined as the pure end-member mineral $\mathrm{Pb}_{14} \mathrm{As}_{6} \mathrm{~S}_{23}$. On the basis of crystal-chemical considerations, the limit composition $\mathrm{Pb}_{14} \mathrm{As}_{2} \mathrm{Sb}_{4} \mathrm{~S}_{23}$ was assumed for geocronite [17], assuming that the As6 site could not be able to host Sb. Actually, As-free geocronite was previously synthesized [33] and crystals having chemical composition $\mathrm{Pb}_{13.95}\left(\mathrm{Sb}_{5.5} \mathrm{As}_{0.4}\right)_{\Sigma 5.9} \mathrm{~S}_{23}$ from Les Cougnasses deposit, Haute-Alpes, France, were described [34]. The members of the geocronite series, having general formula $\mathrm{Pb}_{14}\left(\mathrm{Sb}_{x} \mathrm{As}_{6-x}\right) \mathrm{S}_{23}$, were then divided into three species: (i) jordanite $(0 \leqslant x \leqslant 1 / 3)$; (ii) geocronite $(1 / 3 \leqslant x \leqslant 2 / 3)$; and (iii) schulzite $(2 / 3 \leqslant x \leqslant 1)$ [34]. Finally, the sulfosalt sub-committee of the IMA Commission on Ore Mineralogy [18] defined the jordanite isotypic pair, formed by jordanite, $\mathrm{Pb}_{14}(\mathrm{As}, \mathrm{Sb})_{6} \mathrm{~S}_{23}$, and geocronite, $\mathrm{Pb}_{14}(\mathrm{Sb}, \mathrm{As})_{6} \mathrm{~S}_{23}$, discrediting schulzite. Notwithstanding the IMA recommendation, the latter name continued to be used in the mineralogical literature (e.g., [35]). In our opinion, jordanite and geocronite should be more correctly defined as $\mathrm{Pb}_{14} \mathrm{As}_{6} \mathrm{~S}_{23}$ and $\mathrm{Pb}_{14} \mathrm{Sb}_{6} \mathrm{~S}_{23}$, respectively, owing to the existence of the pure chemical poles of this series (e.g., [33,36]). Consequently, the natural occurrences of these minerals, always showing minor $\mathrm{Sb}$ in jordanite and minor As in geocronite, represent members in the jordanite-geocronite series. The 50 at.\% limit thus separates jordanite samples (As > Sb) from geocronite ( $\mathrm{Sb}>\mathrm{As}$ ).

\subsection{New Insights on the Evolution of Pollone Deposit}

Apuan Alps ore deposits (Pb-Zn-Ag, Hg, Fe-Ba) are preferentially hosted into the Paleozoic formations and at the contact between them and the Mesozoic covers [37] and their present setting is mainly controlled by Apenninic early tectonic $\left(D_{1}\right)$ and late tectonic $\left(D_{2}\right)$ structures $[9,38-40]$. Conversely, field, textural, and isotopic evidence suggests that a number of orebodies predate the Apenninic orogeny [39-41]. The origin of the Pollone ore deposits is still debated [9,10] and it does not represent the main focus of this contribution. However, field observation and measurements collected during jordanite-geocronite sampling provide new details for understanding the evolution of this deposit.

First of all we want to stress the pre- $\mathrm{D}_{2}$ origin of the main orebodies. The baryte + pyrite lenses and the interlayered galena + sphalerite minor lenses are coherently folded and partially re-worked during the $\mathrm{D}_{2}$ stage. Moreover, the new observations performed in the south zone of the deposit suggest a pre- $\mathrm{D}_{1}$ origin of the orebodies. In fact, the relationships between $S_{1}$, ore banding and ore/host-rock contacts are preserved along the $\mathrm{D}_{2}$ fold hinge (Preziosa-Rosina stopes). $\mathrm{S}_{1}$ foliation in host rocks is coherently oriented with baryte + pyrite banding in orebodies and locally it plays as the axial plane foliation of isoclinal $\mathrm{D}_{1}$ folds that involve the original ore/host-rock contacts.

In addition, the "weakly deformed high angle orebodies" described by [9] actually correspond to the extension veins hosting jordanite-geocronite. These veins cannot be considered as true orebodies because they are mainly made by quartz and the accessory amounts of sulfides/sulfosalts were never economically exploited. Most of these veins have a planar geometry while some are sigmoidal or irregular in shape, but there is not evidence for a later folding of the veins. The highly variable nature 
of the host rocks (interlayering of phyllites, quartzites, baryte + pyrite layers, galena + sphalerite lenses) and their differential rheological behavior can be responsible for the observed irregular vein shapes. They represent the last syn-mineralization deformation event recorded at Pollone because they overprint $S_{1}$ and $S_{2}$ foliation as well as ore banding, while they seem to be synchronous with SW-NE fault activity.

The SW-NE faults were characterised by a significant right-lateral component as indicated by the systematic offsets dissecting the main baryte + pyrite orebodies (Figure 1). Such a behaviour is strengthened by the preferential distribution of the extension veins into the overstepping domain between the two main SW-NE faults. This domain may have represented an extensional linking-damage zone (e.g., [42]) that played a fundamental role on the local migration of late hydrothermal fluids from surrounding rocks and their focusing in the extension fractures. The lack of a clear angular relationships (no acute angles; $c a .90^{\circ}$ ) between the main fault plane and the veins prevent reconstruction of the lateral sense of movement and the comparison with information deduced from offsets. This behaviour can be related to the configuration of pre-existing structures (foliation, interlayering of west-dipping ore lenses and schist layers) in the deformed rock volume that influence the deformation pattern in linking-damage zones of strike-slip fault systems (e.g., [43]).

These extension veins are very small in size and they are usually not interconnected. For these reasons, it is quite reasonable that they acted as local drainage systems. Their infill mirror the composition of the local host (baryte-rich veins in Type-1 occurrence; quartz-rich veins in Type- 2 and Type- 3 occurrences) and the physical-chemical characters of local fluids ( $\mathrm{As}^{3+}$-rich environment in veins hosted by baryte + pyrite ore-Type-1 and, to a lesser extent, Type-2). Jordanite-geocronite thus appears as indicator of such a late in situ remobilization process, as it is also probably the case for other peculiar $\mathrm{Pb}$-(Sb/As) sulfosalts (e.g., sterryite, parasterryite) occurring at the Pollone ore deposit.

\section{Conclusions}

The modern crystal-chemical characterization of the members of the jordanite-geocronite isotypic series from the Pollone mine, Valdicastello Carducci, allowed the identification of a series ranging from ideally $\mathrm{Pb}_{14} \mathrm{Sb}_{4} \mathrm{As}_{2} \mathrm{~S}_{23}$ (As-bearing geocronite) to $\mathrm{Pb}_{14} \mathrm{As}_{4} \mathrm{Sb}_{2} \mathrm{~S}_{23}$ (Sb-bearing jordanite). The chemical variability seems to be related to the sample location within the ore deposit, in agreement with previous data [12]. Sb-bearing jordanite and Sb-rich jordanite have been collected in quartz extension veins from pyrite-rich environments (i.e., baryte + pyrite ore bodies or schists interlayered between the orebodies, corresponding to Type-1 and Type-2 occurrences), whereas As-bearing geocronite was collected in quartz extension veins hosted in schists at the contact with pyrite-poor baryte orebodies. Consequently, the crystal-chemistry of the members of the jordanite-geocronite pair at the orebody scale could reflect different $f\left(\mathrm{~S}_{2}\right)$ values, with higher values favoring the arsenic sulfidation to $\mathrm{As}^{3+}$ and its partitioning in sulfosalt crystal structures. If such a chemical zonation would be confirmed, the compositional similarity between sample B and the historical specimens kept in the mineralogical collection of the Pisa University could suggest that the latter were found in the Pozzo Alessandro stope during the 19th Century mining works.

The As-to-Sb substitution takes place preferentially at the Sb4 and As6 sites, whereas only members having Sb contents higher than 4 apfu should host $\mathrm{Sb}$ at the As11 site. This observation does not agree with the previous structural refinement of geocronite [17] but seems to be confirmed by other crystal-chemical data on jordanite homologues (e.g., [19]). Future works on specimens having chemical compositions closer to the ideal geocronite endmember, $\mathrm{Pb}_{14} \mathrm{Sb}_{6} \mathrm{~S}_{23}$, could complete the knowledge about the crystal-chemistry of the jordanite-geocronite isotypic pair.

Supplementary Materials: The CIFs related to the three structural refinements of the members of the jordanite-geocronite series from the Pollone mine are available online at www.mdpi.com/2075-163X/6/1/15/s1, CIF1 Sb-bearing jordanite, CIF2 Sb-rich jordanite, CIF3 As-bearing geocronite.

Acknowledgments: Stefano Magnanelli provided us with the specimen of Sb-bearing jordanite. Electron-microprobe analyses at the BRGM-CNRS-University common laboratory (Orléans, France) were performed with the help 
of Olivier Rouer. The University Centrum for Applied Geosciences (UCAG) is thanked for the access to the Eugene Friedrich Stumpfl electron microprobe laboratory. This research received support by MIUR (Ministero dell'Istruzione, dell'Università e della Ricerca) through the project SIR 2014 "THALMIGEN-Thallium: Mineralogy, Geochemistry, and Environmental Hazards", granted to Cristian Biagioni. The paper benefited from the careful revision of two anonymous referees.

Author Contributions: Cristian Biagioni, Andrea Dini, and Paolo Orlandi conceived and designed the experiments; Cristian Biagioni performed the single-crystal X-Ray diffraction study; Cristian Biagioni, Yves Moëlo, and Marco Pasero analyzed the crystal structure data; Andrea Dini collected geological data on the hydrothermal veins; and Yves Moëlo and Federica Zaccarini collected electron-microprobe data.

Conflicts of Interest: The authors declare no conflict of interest.

\section{References}

1. Walia, D.S.; Chang, L.L.Y. Investigations in the system $\mathrm{PbS}-\mathrm{Sb}_{2} \mathrm{~S}_{3}-\mathrm{As}_{2} \mathrm{~S}_{3}$ and $\mathrm{PbS}-\mathrm{Bi}_{2} \mathrm{~S}_{3}-\mathrm{As}_{2} \mathrm{~S}_{3}$. Can. Mineral. 1973, 12, 113-119.

2. Vom Rath, G. Mineralogische mittheilungen. III. Der jordanit. Ann. Phys. Chem. 1864, 122, 371-408. [CrossRef]

3. Kerndt, T. Über die Krystallform und die chemische Zusammensetzung des Geo-Kronits von Val di Castello. Ann. Phys. 1845, 141, 302-307. (In German) [CrossRef]

4. D'Achiardi, A. Mineralogia della Toscana; Tipografia Nistri: Pisa, Italy, 1872; Volume II, p. 366.

5. D'Achiardi, G. Geocronite di Val di Castello presso Pietrasanta (Toscana). Atti Soc. Toscana Sci. Nat. Mem. 1902, 18, 35-48. (In Italian)

6. Solly, R.H.; Jackson, H. Sulpharsenites of lead from the Binnenthal. Part I. General description and chemical analyses, with a crystallographic account of jordanite. Mineral. Mag. 1900, 12, 282-297. [CrossRef]

7. Amodio Morelli, L.; Menchetti, S. Su alcuni minerali della zona del Bottino e del Canale dell'Angina-Zulfello, Alpi Apuane. Atti Soc. Toscana Sci. Nat. Mem. 1969, 76, 417-445. (In Italian)

8. Carmignani, L.; Dessau, G.; Duchi, G. I giacimenti a barite, pirite e ossidi di ferro delle Alpi Apuane. Studio minerogenetico e strutturale. Nuove osservazioni sui giacimenti polimetallici. Boll. Soc. Geol. Ital. 1976, 95, 1009-1061. (In Italian).

9. Costagliola, P.; Benvenuti, M.; Lattanzi, P.; Tanelli, G. Metamorphogenic barite-pyrite (Pb-Zn-Ag) veins at Pollone, Apuane Alps, Tuscany: Vein geometry, geothermobarometry, fluid inclusions and geochemistry. Mineral. Petrol. 1998, 62, 29-60. [CrossRef]

10. Carmignani, L.; Dessau, G.; Duchi, G. Una mineralizzazione sin-tettonica: II giacimento di Valdicastello (Alpi Apuane). Rapporti tra tettonica e minerogenesi in Toscana. Boll. Soc. Geol. Ital. 1975, 24, 725-758. (In Italian)

11. Frizzo, P.; Simone, S. Diaphorite in the Pollone ore deposit (Apuan Alps, Tuscany, Italy). Eur. J. Mineral. 1995, 7, 705-708.

12. Biagioni, C.; Orlandi, P.; Moëlo, Y.; Pardini, S.; Passarino, G. Sterryite e parasterryite. I solfosali aciculari di piombo e argento della miniera del Pollone (Pietrasanta, Lucca). Riv. Mineral. Ital. 2012, 36, 76-91. (In Italian)

13. Bruker AXS Inc. APEX 2. In Bruker Advanced X-Ray Solutions; Bruker AXS Inc.: Madison, WI, USA, 2004.

14. Sheldrick, G.M. A short history of SHELX. Acta Crystallogr. 2008, A64, 112-122. [CrossRef] [PubMed]

15. Ito, T.; Nowacki, W. The crystal structure of jordanite, $\mathrm{Pb}_{28} \mathrm{As}_{12} \mathrm{~S}_{46}$. Z. Kristallogr. Cryst. Mater. 1974, 139, 161-185. [CrossRef]

16. Wilson, A.J.C. (Ed.) Volume C: Mathematical, physical and chemical tables. In International Tables for Crystallography; Kluwer Academic: Dordrecht, The Netherlands, 1992.

17. Birnie, R.W.; Burnham, C.W. The crystal structure and extent of solid solution of geocronite. Am. Mineral. 1976, 61, 963-970.

18. Moëlo, Y.; Makovicky, E.; Mozgova, N.N.; Jambor, J.L.; Cook, N.; Pring, A.; Paar, W.H.; Nickel, E.H.; Graeser, S.; Karup-Møller, S.; et al. Sulfosalt systematics: A review. Report of the sulfosalt sub-committee of the IMA Commission on ore mineralogy. Eur. J. Mineral. 2008, 20, 7-46. [CrossRef]

19. Makovicky, E.; Balić-Žunić, T.; Karanović, L.; Poleti, D. The crystal structure of kirkiite, $\mathrm{Pb}_{10} \mathrm{Bi}_{3} \mathrm{As}_{3} \mathrm{~S}_{19}$. Can. Mineral. 2006, 44, 177-188. [CrossRef]

20. Biagioni, C.; Orlandi, P.; Moëlo, Y.; Bindi, L. Lead-antimony sulfosalts from Tuscany (Italy). XVI. Carducciite, $(\mathrm{AgSb}) \mathrm{Pb}_{6}(\mathrm{As}, \mathrm{Sb})_{8} \mathrm{~S}_{20}$, a new Sb-rich derivative of rathite from the Pollone mine, Valdicastello Carducci: Occurrence and crystal structure. Mineral. Mag. 2014, 78, 1775-1793. [CrossRef] 
21. Topa, D.; Keutsch, F.N.; Makovicky, E.; Kolitsch, U.; Paar, W. Polloneite, IMA 2014-093. CNMNC Newsletter No. 24, April 2015, page 249. Mineral. Mag. 2015, 79, 247-251.

22. Biagioni, C.; Moëlo, Y.; Orlandi, P. Apuan Alps: A reference district for the study of sulfosalt crystal-chemistry. Rend. Online Soc. Geol. Ital. 2014, 31 (Suppl. S1), 305.

23. Einaudi, M.T.; Hedenquist, J.W.; Inan, E.E. Sulfidation state of fluids in active and extinct hydrothermal systems: Transitions from porphyry to epithermal environments. In Volcanic, Geothermal, and Ore-Forming Fluids: Rulers and Witnesses of Processes within the Earth; Simmons, S.F., Graham, I., Eds.; Society of Economic Geologists: Littleton, CO, USA, 2005; pp. 285-313.

24. Barton, P.B., Jr. Sulfide petrology. Mineral. Soc. Am. Spec. Pap. 1970, 3, 187-198.

25. Svanberg, L.F. Undersökning af Geokronit och Hydrofit, tvenne inom Sverige förekommande nya mineralier. Kongliga Sven. Vetensk. Acad. Handl. 1839, 27, 184-187. (In Swedish)

26. Svanberg, L.F. Untersuchung des geokronit und hydrophit, zweier in Schweden vorkommenden neuen mineralien. Ann. Phys. Chem. 1840, 21, 535-538. (In German). [CrossRef]

27. Sauvage, M. Sur un sulfure double d'antimoine et de plomb de Mérédo, province de Galice (Espagne). Ann. Mines 1840, 17, 525-528. (In French)

28. Apjohn, J. On a new lead ore from Kilbricken mine, County of Clare. Proc. R. Ir. Acad. 1841, 1, 469-473.

29. Hausmann, J.F.L. Schulzite. Handb. Mineral. 1847, 2, 166.

30. Prior, G.T. The identity of kilbrickenite with geocronite and analyses of miersite, marshite, and copper-pyrites. Mineral. Mag. 1902, 13, 186-190. [CrossRef]

31. Phillips, W.; Brooke, H.J.; Miller, W.H. An Elementary Introduction to Mineralogy; Gilbert and Rivington Printers: London, UK, 1852; p. 700.

32. Douglass, R.M.; Murphy, M.J.; Pabst, A. Geocronite. Am. Mineral. 1954, 39, 908-928.

33. Jambor, J.L. New lead sulfantimonides from Madoc, Ontario Part 3-Syntheses, paragenesis, origin. Can. Mineral. 1968, 9, 505-521.

34. Moëlo, Y. Contribution à L'étude des Conditions Naturelles de Formation des Sulfures Complexes D'antimoine et Plomb; Document du BRGM; BRGM: Orléans, France, 1983; Volume 55. (In French)

35. Bryzgalov, I.A.; Krivitskaya, N.N.; Spiridonov, E.M. First find of the minerals of jordanite-geocronite-schulzite in one deposit (Darasun, Eastern Transbaikalia). Dokl. Earth Sci. 2011, 438, 815-818. [CrossRef]

36. Roland, G.W. The system Pb-As-S. Composition and stability of jordanite. Miner. Depos. 1968, 3, $249-260$. [CrossRef]

37. Lattanzi, P.; Benvenuti, M.; Costagliola, P.; Tanelli, G. An overview on recent research on the metallogeny of Tuscany, with special reference to the Apuane Alps. Mem. Soc. Geol. Ital. 1994, 48, 613-625.

38. Carmignani, L.; Dessau, G.; Duchi, G. Structural control of mineralization in the Apuane Alps (Tuscany, Italy). Verh. Geol. B-A 1978, 3, 279-283.

39. Benvenuti, M.; Cortecci, G.; Costagliola, P.; Lattanzi, P.; Ruggieri, G.; Tanelli, G. The metamorphic-hosted precious- and base-metal deposits of the Bottino-Valdicastello region (Apuane Alps, Tuscany): An overview. Acta Vulcanol. 1992, 2, 45-54.

40. Dini, A.; Benvenuti, M.; Costagliola, P.; Lattanzi, P. Mercury deposits in metamorphic settings: The example of Levigliani and Ripa mines, Alpi Apuane (Tuscany, Italy). Ore Geol. Rev. 2001, 18, 149-167. [CrossRef]

41. Lattanzi, P.; Hansmann, W.; Koeppel, V.; Costagliola, P. Source of metals in metamorphic ore-forming processes in the Apuane Alps (NW Tuscany, Italy): Constraints by Pb-isotope data. Mineral. Petrol. 1992, 45, 217-229. [CrossRef]

42. Kim, Y.-S.; Peacock, D.C.P.; Sanderson, D.J. Fault damage zones. J. Struct. Geol. 2004, 26, 503-517. [CrossRef]

43. Brogi, A. Variation in fracture patterns in damage zones related to strike-slip faults interfering with pre-existing fractures in sandstone (Calcione area, southern Tuscany, Italy). J. Struct. Geol. 2011, 33, 644-661. [CrossRef]

(C) 2016 by the authors; licensee MDPI, Basel, Switzerland. This article is an open access article distributed under the terms and conditions of the Creative Commons by Attribution (CC-BY) license (http://creativecommons.org/licenses/by/4.0/). 